\title{
Large-scale distribution patterns of virioplankton in the upper ocean
}

\author{
Yanhui Yang ${ }^{1,2,3}$, Chiaki Motegi ${ }^{1,2,4,5}$, Taichi Yokokawa ${ }^{2,6}$, Toshi Nagata ${ }^{1,2,3, *}$ \\ ${ }^{1}$ Ocean Research Institute, The University of Tokyo, Tokyo 164-8639, Japan \\ ${ }^{2}$ Center for Ecological Research, Kyoto University, Otsu, Shiga, 520-2113, Japan \\ ${ }^{3}$ Present address: Atmosphere and Ocean Research Institute, The University of Tokyo, 5-1-5 Kashiwanoha, \\ Kashiwa, Chiba 277-8564, Japan \\ ${ }^{4}$ Present address: Université Pierre et Marie Curie-Paris 6, Laboratoire d'Océanographie de Villefranche, \\ BP 28, 06230 Villefranche-sur-Mer Cedex, France \\ ${ }^{5}$ Present address: CNRS, Laboratoire d'Océanographie de Villefranche, BP 28, 06230 Villefranche-sur-Mer Cedex, France \\ ${ }^{6}$ Present address: Department of Biological Oceanography, Royal Netherlands Institute for Sea Research (NIOZ), \\ PO Box 59, 1790 AB Den Burg, Netherlands
}

\begin{abstract}
We used flow cytometry to investigate large-scale distribution patterns of viruses and their subclusters in the upper $200 \mathrm{~m}$ water column of the central Pacific Ocean and the Pacific sector of the Southern Ocean. The abundances of 3 groups of photoautotrophic picoplankton (APP), including Synechococcus, picoeukaryotes, and Prochlorococcus, accounted for a large fraction of viral abundance variability $\left(\mathrm{r}^{2}=0.570, \mathrm{n}=354, \mathrm{p}<0.001\right)$. The relative contribution of the viral subcluster with high fluorescence intensity (HV) increased with increasing abundance of APP. These data are consistent with the notion that viruses infecting APP are abundant, and the HV subcluster might contain large numbers of these viruses especially in subtropical and tropical oceans. Relationships between viral abundance and biotic variables differed among regions, indicating that controls of virus-host systems are largely distinct among different oceanic regions. We found a conspicuous peak of viral abundance in the mid-latitude region of the North Pacific. This 'viral hot spot' coincided with a dissolved oxygen anomaly (the excess above saturation) indicated by negative values ( -15 to $-59 \mu \mathrm{mol} \mathrm{kg}{ }^{-1}$ ) of apparent oxygen utilization. Our results support the notion that large-scale distribution patterns of viruses and their subclusters in the upper oceans are affected by a combined effect of host distributions and physical processes.
\end{abstract}

KEY WORDS: Virioplankton · Viral subclusters · Flow cytometry · Photoautotrophic picoplankton · Pacific Ocean · Southern Ocean

\section{INTRODUCTION}

Viruses are widespread, abundant, and important agents of bacterial (Breitbart et al. 2008) and algal mortality (Baudoux et al. 2007, Suttle 2007) in the sea, exerting major influences on microbial diversity and biogeochemical cycling (Fuhrman 1999, Motegi et al. 2009). However, little is known about the distribution patterns of viral abundance across different oceanic regions. Spatial variability in physical forcing, such as the mixing of water columns and photon irradiations, largely explains the occurrence of diverse biogeochemical provinces, which are characterized by different levels and seasonal patterns in primary productivity and are accompanied by distinctive community structures and modes of carbon and nutrient cycles (Longhurst 2006). Understanding viral distributions under diverse physical and biogeochemical settings along large-scale oceanographic gradients may help to identify principal mechanisms by which viral popula- 
tions are controlled; hence, this is an essential initial step toward the embedment of viruses into the models of oceanic ecosystems and biogeochemical cycles.

Because viral proliferation depends on the metabolism of host cells, the abundance and activity of these hosts may primarily determine viral distributions in the oceans. Bacteria and photoautotrophic picoplankton (APP) are the most abundant and probably the major hosts of viruses in the upper oceans (Fuhrman 1999, Mann 2003). Consistent with this notion, previous studies have found that viral abundance is strongly positively correlated with bacterial abundance in some oceanic regions (Steward et al. 1996, Culley \& Welschmeyer 2002). Little information is available about the relationship between viral abundance and APP. A recent study suggested that viruses infecting APP might be abundant in subtropical waters. At Stn ALOHA off the coast of Hawaii (subtropical North Pacific), metagenomic analysis of viral genes in a picoplankton fraction $(0.22$ to $1.6 \mu \mathrm{m})$ revealed that 60 to $80 \%$ of the total viral sequences in the photic zone were apparently those of cyanophages (DeLong et al. 2006), which suggests a considerable contribution of cyanophages to viral production. The relative importance of APP and bacteria in influencing variations in viral abundance on a global scale remains unclear.

In addition to host abundance, factors that cause the loss of viruses may also account for the variations in viral abundance. These factors include UV radiation (Heldal \& Bratbak 1991, Suttle \& Chen 1992, Noble \& Fuhrman 1997), extracellular proteases (Noble \& Fuhrman 1997, Motegi \& Nagata 2009), colloidal organic matter (Proctor \& Fuhrman 1991), scavenging by large particles (Proctor \& Fuhrman 1991), capsid decay due to internal pressure (De Paepe \& Taddei 2006), and protist grazing (Gonzalez \& Suttle 1993). One theory predicted that interactive effects of mixing processes and UV radiation can largely affect viral dynamics in oceanic water columns (Murray \& Jackson 1993). However, it is not entirely clear how these multiple forces shape large-scale viral distributions in the upper oceans.

Flow cytometry has become a powerful tool to determine viral abundance in seawater (Marie et al. 1999, Brussaard 2004), allowing investigators to discriminate 2 or 3 subclusters of viruses on the basis of the fluorescence intensity of the dye bound to viral nucleic acids (Marie et al. 1999, Li \& Dickie 2001, Brussaard et al. 2008). Several studies have found that different subclusters display different patterns in distributions and dynamics in marine systems, leading to the proposition that the flow cytometric discrimination of viral subclusters may help to discern between viruses infecting bacteria and those infecting algae (Marie et al. 1999, Li \& Dickie 2001, Suttle 2007, Brussaard et al. 2008, Larsen et al. 2008). However, few studies have examined distributions of different viral subclusters across oceanic regions with largely different compositions of host communities.

Here, we examined distributions of viruses in the upper water column (0 to $200 \mathrm{~m}$ ) at 38 stations along 3 transects deployed in broad regions of the central Pacific and Southern Oceans. Abundances of viruses, bacteria, and APP (Prochlorococcus, Synechococcus, and picoeukaryotes) were counted using flow cytometry (Campbell 2001, Brussaard 2004). We explored distribution patterns of viral abundance and their subclusters in the upper water column. The purposes of this study were to (1) examine how viral abundance and subcluster compositions are related to distributions of bacteria (abundance and production) and APP, and (2) analyze possible relationships between distributions of viruses and oceanographic parameters over a large spatial scale.

\section{MATERIALS AND METHODS}

Sample waters were collected aboard the RV 'Hakuho-maru' during 2 summer cruises: KH04-5 (December 2004 to March 2005) and KH 05-2 (August to September 2005). A total of 38 stations were occupied to cover a broad range of oceanic regions in the Southern and Pacific Oceans (Fig. 1; see also Table 1 for details on sampling sites and oceanic regions). At each station, sample waters were collected at 10 or 11

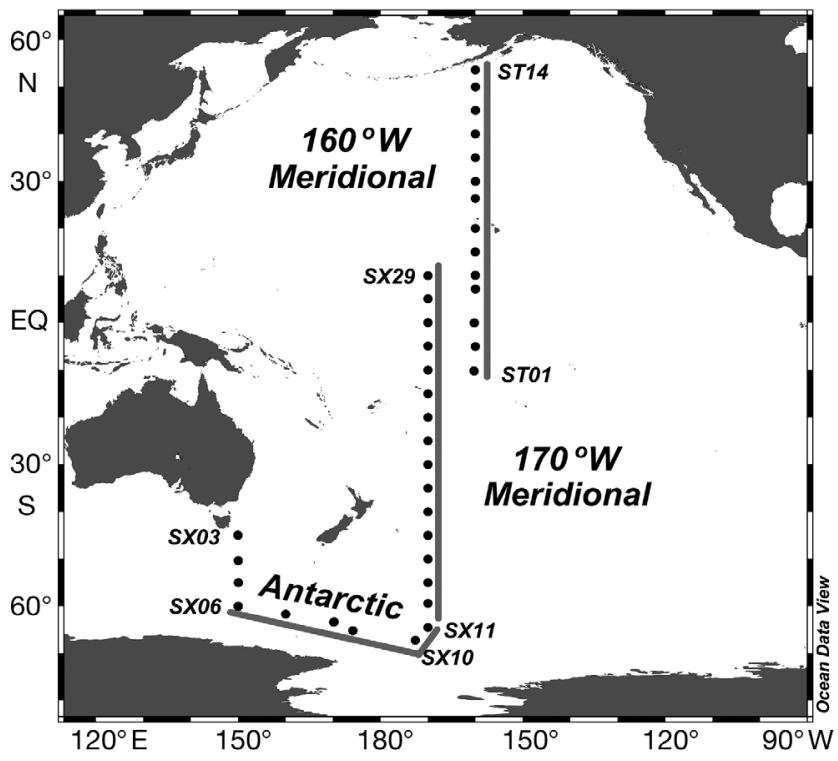

Fig. 1. Sampling stations occupied during cruises KH04-5 and KH05-2. The map was created using Ocean Data View (http://odv.awi.de/). Station codes are included for selected stations. Stations along 3 transect lines were used to create contour graphs (Figs. 2, 4, \& 5) 
Table 1. Sampling date, geographic position, surface water temperature, and $\mathrm{NO}_{3}$ concentration of each station during cruises KH04-5 (Stns SX03-SX29) and KH05-2 (Stns ST01-ST14; data are from the Cruise Report, Ocean Research Institute, The University of Tokyo). Six oceanic regions were distinguished according to Longhurst (2006), on the basis of physical and biogeochemical features, although some adjacent provinces were combined so that each regional category contained at least 4 stations

\begin{tabular}{|c|c|c|c|c|c|c|}
\hline Region & Station & $\begin{array}{l}\text { Local date } \\
\text { (dd/mm/yy) }\end{array}$ & $\begin{array}{l}\text { Longitude } \\
\left({ }^{\circ} \mathrm{E}\right)\end{array}$ & $\begin{array}{c}\text { Latitude } \\
\left({ }^{\circ} \mathrm{N}\right)\end{array}$ & $\begin{array}{c}\text { Temperature } \\
\left({ }^{\circ} \mathrm{C}\right)\end{array}$ & $\begin{array}{c}\mathrm{NO}_{3} \\
\left(\mu \mathrm{mol} \mathrm{l}^{-1}\right)\end{array}$ \\
\hline Antarctic region & $\begin{array}{l}\text { SX06 } \\
\text { SX07 } \\
\text { SX08 } \\
\text { SX09 } \\
\text { SX10 } \\
\text { SX11 }\end{array}$ & $\begin{array}{l}23 / 12 / 04 \\
24 / 12 / 04 \\
26 / 12 / 04 \\
28 / 12 / 04 \\
31 / 12 / 04 \\
02 / 01 / 05\end{array}$ & $\begin{array}{r}150.0 \\
160.0 \\
170.1 \\
174.2 \\
-172.7 \\
-170.0\end{array}$ & $\begin{array}{l}-60.0 \\
-61.7 \\
-63.4 \\
-65.1 \\
-67.2 \\
-64.5\end{array}$ & $\begin{array}{r}0.8 \\
0.8 \\
0.8 \\
-0.4 \\
-0.5 \\
0.3\end{array}$ & $\begin{array}{l}28.56 \\
27.39 \\
25.95 \\
23.72 \\
23.31 \\
25.67\end{array}$ \\
\hline $\begin{array}{l}\text { Subantarctic \& } \\
\text { subtropical } \\
\text { convergence } \\
\text { zone }\end{array}$ & $\begin{array}{l}\text { SX03 } \\
\text { SX04 } \\
\text { SX05 } \\
\text { SX12 } \\
\text { SX13 } \\
\text { SX14 } \\
\text { SX15 } \\
\text { SX17 }\end{array}$ & $\begin{array}{l}19 / 12 / 04 \\
20 / 12 / 04 \\
21 / 12 / 04 \\
04 / 01 / 05 \\
06 / 01 / 05 \\
07 / 01 / 05 \\
09 / 01 / 05 \\
11 / 01 / 05\end{array}$ & $\begin{array}{r}149.9 \\
150.0 \\
150.0 \\
-170.0 \\
-170.0 \\
-170.0 \\
-170.0 \\
-170.0\end{array}$ & $\begin{array}{l}-44.9 \\
-50.3 \\
-55.0 \\
-59.4 \\
-55.0 \\
-50.0 \\
-45.0 \\
-40.0\end{array}$ & $\begin{array}{r}13.9 \\
8.8 \\
7.2 \\
4.6 \\
7.2 \\
11.3 \\
14.9 \\
16.3\end{array}$ & $\begin{array}{r}3.34 \\
15.76 \\
17.75 \\
21.38 \\
19.29 \\
10.49 \\
0.71 \\
<0.05\end{array}$ \\
\hline $\begin{array}{l}\text { South Pacific } \\
\text { subtropical } \\
\text { region }\end{array}$ & $\begin{array}{l}\text { SX19 } \\
\text { SX20 } \\
\text { SX21 } \\
\text { SX22 } \\
\text { SX24 }\end{array}$ & $\begin{array}{l}23 / 01 / 05 \\
27 / 01 / 05 \\
29 / 01 / 05 \\
31 / 01 / 05 \\
21 / 02 / 05\end{array}$ & $\begin{array}{l}-170.0 \\
-170.0 \\
-170.0 \\
-170.0 \\
-170.0\end{array}$ & $\begin{array}{l}-35.0 \\
-30.0 \\
-25.0 \\
-20.0 \\
-15.0\end{array}$ & $\begin{array}{l}19.6 \\
23.7 \\
26.4 \\
28.6 \\
29.6\end{array}$ & $\begin{array}{l}<0.05 \\
<0.05 \\
<0.05 \\
<0.05 \\
<0.05\end{array}$ \\
\hline Equatorial region & $\begin{array}{l}\text { SX25 } \\
\text { SX26 } \\
\text { SX27 } \\
\text { SX28 } \\
\text { SX29 } \\
\text { ST01 } \\
\text { ST02 } \\
\text { ST03 } \\
\text { ST04 } \\
\text { ST05 }\end{array}$ & $\begin{array}{l}23 / 02 / 05 \\
25 / 02 / 05 \\
27 / 02 / 05 \\
01 / 03 / 05 \\
03 / 03 / 05 \\
19 / 08 / 05 \\
21 / 08 / 05 \\
22 / 08 / 05 \\
24 / 08 / 05 \\
24 / 08 / 05\end{array}$ & $\begin{array}{l}-170.0 \\
-170.0 \\
-170.0 \\
-170.0 \\
-170.0 \\
-160.3 \\
-160.0 \\
-160.2 \\
-160.0 \\
-160.0\end{array}$ & $\begin{array}{r}-10.0 \\
-4.9 \\
0.1 \\
5.1 \\
10.0 \\
-10.2 \\
-5.0 \\
0.0 \\
7.2 \\
10.1\end{array}$ & $\begin{array}{l}29.2 \\
29.1 \\
28.7 \\
28.7 \\
27.4 \\
29.0 \\
28.3 \\
27.5 \\
28.9 \\
27.9\end{array}$ & $\begin{array}{r}<0.05 \\
<0.05 \\
2.68 \\
0.27 \\
<0.05 \\
<0.05 \\
4.55 \\
4.28 \\
0.06 \\
0.13\end{array}$ \\
\hline $\begin{array}{l}\text { North Pacific } \\
\text { subtropical } \\
\text { region }\end{array}$ & $\begin{array}{l}\text { ST06 } \\
\text { ST07 } \\
\text { ST08 } \\
\text { ST09 } \\
\text { ST10 }\end{array}$ & $\begin{array}{l}26 / 08 / 05 \\
27 / 08 / 05 \\
04 / 09 / 05 \\
04 / 09 / 05 \\
06 / 09 / 05\end{array}$ & $\begin{array}{l}-160.0 \\
-160.0 \\
-160.0 \\
-160.0 \\
-160.0\end{array}$ & $\begin{array}{l}15.0 \\
20.0 \\
26.3 \\
30.0 \\
35.0\end{array}$ & $\begin{array}{l}27.1 \\
27.0 \\
27.2 \\
26.6 \\
25.1\end{array}$ & $\begin{array}{l}<0.05 \\
<0.05 \\
<0.05 \\
<0.05 \\
<0.05\end{array}$ \\
\hline $\begin{array}{l}\text { Subarctic \& North } \\
\text { Pacific transition } \\
\text { zone }\end{array}$ & $\begin{array}{l}\text { ST11 } \\
\text { ST12 } \\
\text { ST13 } \\
\text { ST14 }\end{array}$ & $\begin{array}{l}07 / 09 / 05 \\
09 / 09 / 05 \\
10 / 09 / 05 \\
12 / 09 / 05\end{array}$ & $\begin{array}{l}-160.0 \\
-160.0 \\
-160.0 \\
-160.0\end{array}$ & $\begin{array}{l}40.0 \\
45.0 \\
50.0 \\
53.6\end{array}$ & $\begin{array}{l}20.2 \\
16.0 \\
12.6 \\
12.5\end{array}$ & $\begin{array}{r}0.06 \\
7.39 \\
11.70 \\
<0.05\end{array}$ \\
\hline
\end{tabular}

different depths in the upper $200 \mathrm{~m}$ by using clean 121 Niskin-X bottles (General Oceanics) attached to a water sampler equipped with a conductivity-temperature-depth profiler (Sea-Bird Electronics, Model 9 plus). Surface seawater samples were collected using a clean bucket.

Samples for the measurement of the viral abundance, bacteria, and APP were maintained in $2 \mathrm{ml}$ capacity cryovials (Nalgene) and fixed with $0.02 \mu \mathrm{m}$ filtered (25 mm syringe-type Whatman Anotop filters) glutaraldehyde to a final concentration of $1 \%$. After fixation for $30 \mathrm{~min}$ in the dark, the samples were frozen in a deep freezer $\left(-80^{\circ} \mathrm{C}\right.$; cruise $\left.\mathrm{KH} 04-5\right)$ or in liquid nitrogen (cruise KH05-2). The frozen samples were preserved in a deep freezer for later analysis using a flow cytometer (FACSCalibur, Becton Dickinson) equipped with a $15 \mathrm{~mW}, 488 \mathrm{~nm}$ air-cooled argon-ion laser and standard filter set. Viruses were counted according to Marie et al. (1999) and Brussaard (2004) with modifications. After thawing, samples were diluted (50 to $200 \times)$ with TE buffer $\left(10 \mathrm{mmol} \mathrm{l}^{-1}\right.$ Tris$\mathrm{HCl}, 1 \mathrm{mmol} \mathrm{l}^{-1}$ EDTA acid, pH 8.0, Wako, filtered through $0.02 \mu \mathrm{m}$ Whatman Anotop filters). Samples were spiked with SYBR Green I at a final concentration of $5 \times 10^{-5}$ dilution of commercial stock (Molecular Probes) and incubated at $80^{\circ} \mathrm{C}$ for $10 \mathrm{~min}$, followed by 
cooling to room temperature in the dark. Yellow-green beads of $1 \mu \mathrm{m}$ (Molecular Probes) were then added to the samples as an internal standard of the fluorescence intensity. Samples were run for at least 3 min with event rates of 100 to 400 counts s${ }^{-1}$. The data obtained for green fluorescence (FL1) and side scatter (SSC) were collected for analysis using CellQuest software (Becton Dickinson). Duplicate or triplicate blanks (SYBR Green I and TE buffer were mixed, heated, and amended with beads) were run for every 8 to 10 samples. Blank values $(<5 \%$ of total counts) were subtracted to derive virus counts. Flow rates were determined at least twice a day by weighing the TE buffer before and after the injection for $10 \mathrm{~min}$, and these rates were multiplied by the running time to calculate virus abundance (Campbell 2001). The average daily flow rate variation was 2 to $3 \%$. Viral subclusters were distinguished on the basis of FL1 intensity (see 'Results'). Fixed gates were used for all samples using constant voltage settings. Conditions for staining and counting were carefully controlled to minimize the noise due to reagents, sheath fluids, and optics. Errors in counts associated with flow fluctuations were also minimized by intensive maintenance of fluid delivery system. Deviation between duplicate viral counts was typically 4 to $7 \%$ of the average value.

For counting non-pigmented prokaryotes (bacteria), sample waters were stained with SYBR Green I (final concentration $10^{-4}$ dilution of commercial stock) for 15 to $30 \mathrm{~min}$ at room temperature in the dark, spiked with the standard beads, and injected into the flow cytometer. When event rates exceeded 400 counts s$^{-1}$, samples were reanalyzed after dilution with TE buffer (10x). For APP counts, water samples were spiked with the standard beads and injected into the flow cytometer. The cytograms that relate red fluorescence (FL3) to SSC, orange fluorescence (FL2) to SSC, FL2 to FL3, and SSC to forward scatter (FSC) were analyzed to discriminate among Prochlorococcus, Synechococcus, and picoeukaryotes (Campbell 2001). Deviations between duplicate counts were typically 2 to $4 \%$ of the average values.

Bacterial production rate was estimated from the incorporation of ${ }^{3} \mathrm{H}$-leucine (Kirchman 2001). Subsamples $(1.5 \mathrm{ml})$ were contained in screw-capped centrifuge tubes ( $2 \mathrm{ml}$ capacity, ISI), spiked with $10 \mathrm{nmol}$ $\mathrm{I}^{-1}$ of ${ }^{3} \mathrm{H}$-leucine (Amersham TRK510), and incubated at in situ temperature $\left( \pm 2^{\circ} \mathrm{C}\right)$ in the dark. Triplicate samples and 1 trichloroacetic acid (TCA)-killed control were prepared. After incubation for $1 \mathrm{~h}$, samples were extracted with $5 \%$ TCA and ice-cold $80 \%$ ethanol using a microcentrifuge. Pellets were dried, mixed with a scintillation cocktail (Ultima-Gold, Packard), and radioassayed with a liquid scintillation counter (Wallac 1414) with quench corrections. The coeffi- cients of variation of triplicate measurements were typically less than $10 \%$. Leucine incorporation rate was converted to bacterial production using a $1.5 \mathrm{~kg} \mathrm{C}$ $\mathrm{mol}^{-1}$ conversion factor (Kirchman 2001).

Chlorophyll a (chl a) concentration was determined fluorometrically after $\mathrm{N}, \mathrm{N}$-dimethylformamide extraction of particles collected on Whatman GF/F filters. Dissolved oxygen concentration was determined by the Winkler method using a high precision titrator (Metrohm, 793 MPT Titrino).

Relationships between viral and environmental variables were analyzed using routines of the Distance Based Linear Model (DISTLM) with an implementation of distance based redundancy analysis (dbRDA) in Permanova+ for Primer v6 (PRIMER-E). Differing from traditional multiple regressions, DISTLM does not assume normality of data distributions because hypotheses are tested by permutations (Anderson et al. 2008). In order to minimize influences of outliers, the variables with skewed distributions (examined on the Draftsman plot) were log transformed. Stepwise procedure was used to select predictor variables that account for the variability of response variables. The Bayesian Information Criterion was used to determine the model that best fit the data with the fewest predictor variables. Multi-collinearity of the predictor variables was checked by calculating the tolerance value for each predictor variable $\left(1-\mathrm{r}^{2}: \mathrm{r}^{2}\right.$ was obtained by the multiple regression that relates a given predictor variable to the rest of the selected variables) with an approximate guide considering that values $<0.1$ are problematic (Quinn \& Keough 2002). In order to build linear regression models that relate viral variables to predictor variables with errors, we conducted Model II regression analyses according to Sokal \& Rohlf (1995). Contour plots were generated using SigmaPlot 2001 (SYSTAT Software).

\section{RESULTS}

\section{Distribution features of biotic variables}

Chl a concentration was highest in the upper water columns of the Antarctic region, followed by the subarctic and transition zone of the North Pacific, whereas it was lowest in the equatorial and subtropical regions (Figs. 2A \& 3A). The subsurface peak of chl a existed at depths of 75 to $125 \mathrm{~m}$ in the subtropical regions of the South and North Pacific (Fig. 2A). Depth integrated $(0-200 \mathrm{~m})$ bacterial abundance was highest in the subantarctic/subtropical convergence zone, where the highest abundance was recorded in the upper water column $(<75 \mathrm{~m})$, and lowest in the Antarctic region (Figs. 2B, 3B). Bacterial production tended to be higher 

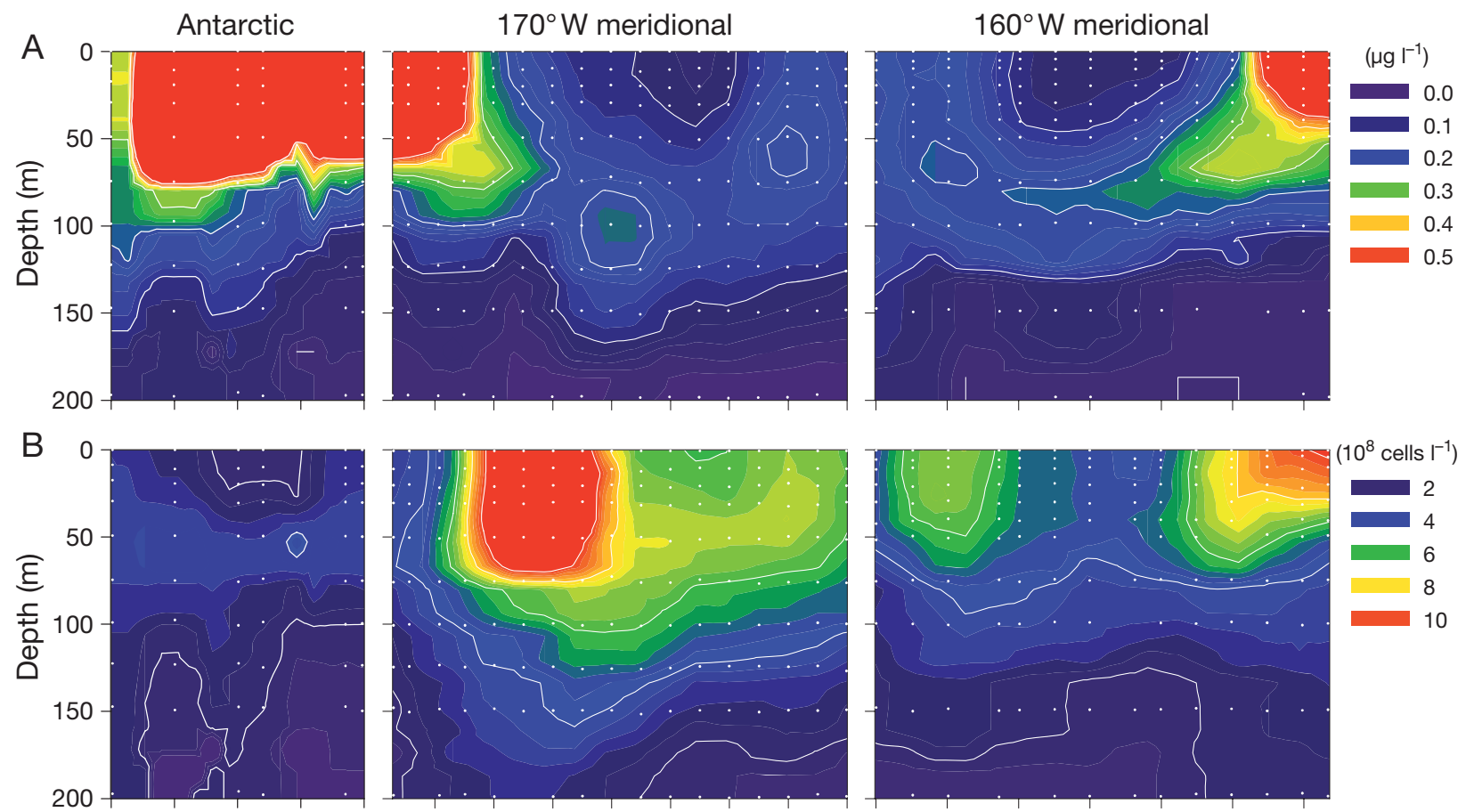

$\left(10^{8}\right.$ cells $\left.\left.\right|^{-1}\right)$
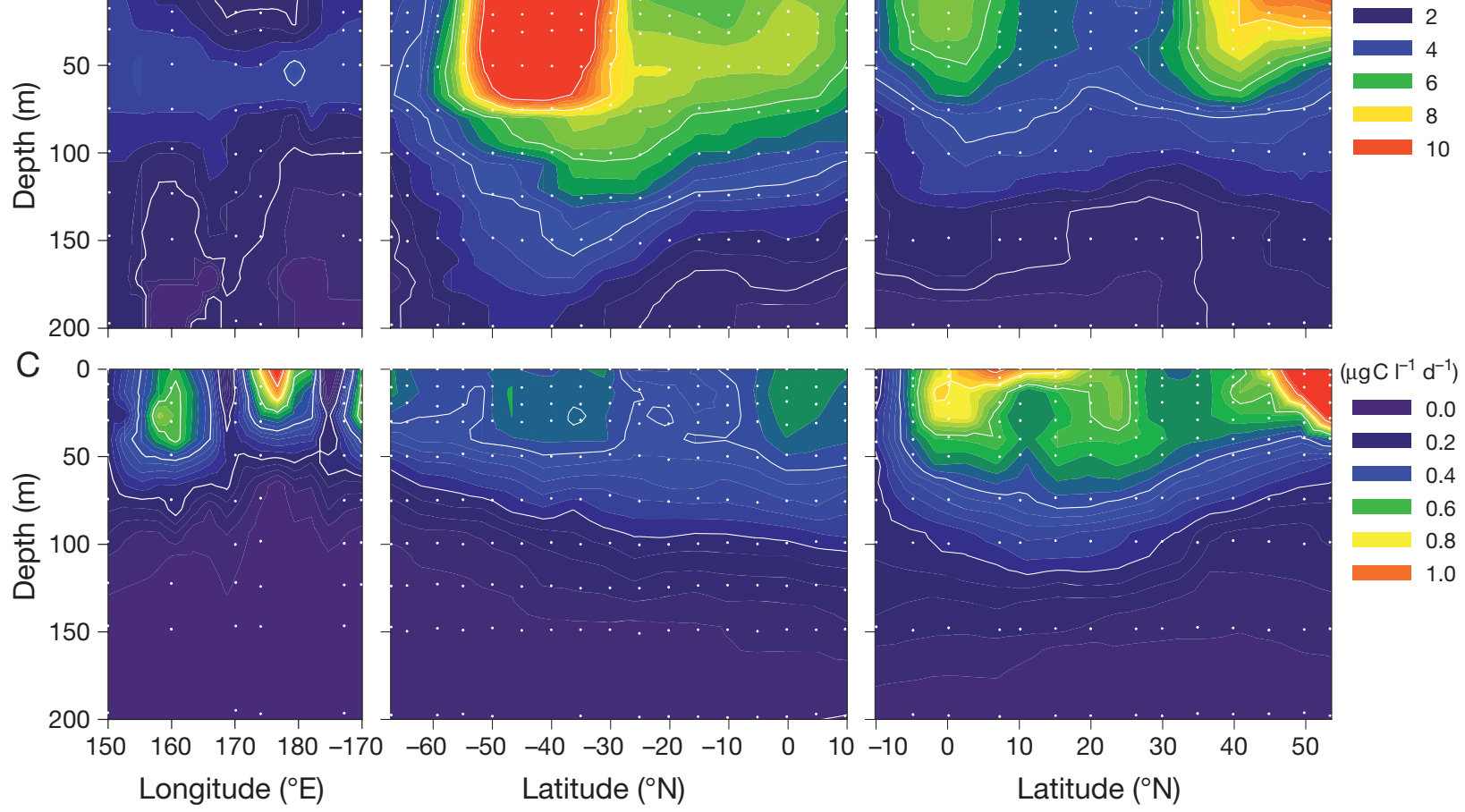

Fig. 2. Distributions of (A) chl a concentration, (B) bacterial abundance, and (C) bacterial production along the 3 transects including the Antarctic (Stns SX06 to SX11), $170^{\circ} \mathrm{W}$ meridional (Stns SX10 to SX29), and 160 ${ }^{\circ}$ W meridional (Stns ST01 to ST14). Stns SX10 and SX11 are included in both the Antarctic and $170^{\circ} \mathrm{W}$ meridional transects. See Fig. 1 and Table 1 for the positions and oceanographic parameters of the stations

in the upper water columns $(<50 \mathrm{~m})$ in equatorial, subtropical, and subarctic regions of the North Pacific (Fig. 2C), although the geographic pattern of the integrated values was less systematic (Fig. 3C). APP abundance was highest, especially in the upper layers $(0-125 \mathrm{~m})$, in equatorial and subtropical regions (Figs. 3D, 4A) where Prochlorococcus dominated the APP community (Fig. 4B). This abundance tended to decrease with increasing latitude, with the lowest integrated values in the Antarctic region (Fig. 3D). Intermediate abundances of APP were found in the subarctic/transition zone and the subantarctic/subtropical convergence zone, where Synechococcus and picoeukaryotes were abundant (Figs. 3D \& 4C,D).

\section{Viral distributions and subclusters}

Viral abundances varied within $1.5 \times 10^{9}$ and $3.2 \times$ $10^{10}$ particles $1^{-1}$, which tended to decrease with depth, except for a low abundance in the surface layer $(<20-40 \mathrm{~m})$ in a broad area of subtropical regions $\left(10-30^{\circ} \mathrm{N}\right.$ and $10-30^{\circ} \mathrm{S}$; Fig. 5A). We found a conspicuous peak of viral abundance in the mid-latitude region of the North Pacific (between $25^{\circ}$ and $45^{\circ} \mathrm{N}$ ) at depths of 20 to $75 \mathrm{~m}$ (Fig. 5A). In accordance with these high values, the depth-integrated viral abundances were highest across the boundary of subtropical and subarctic gyres (Stns. 10 and 11; Fig. 3E). Excluding these data, the depth-integrated viral abundances 

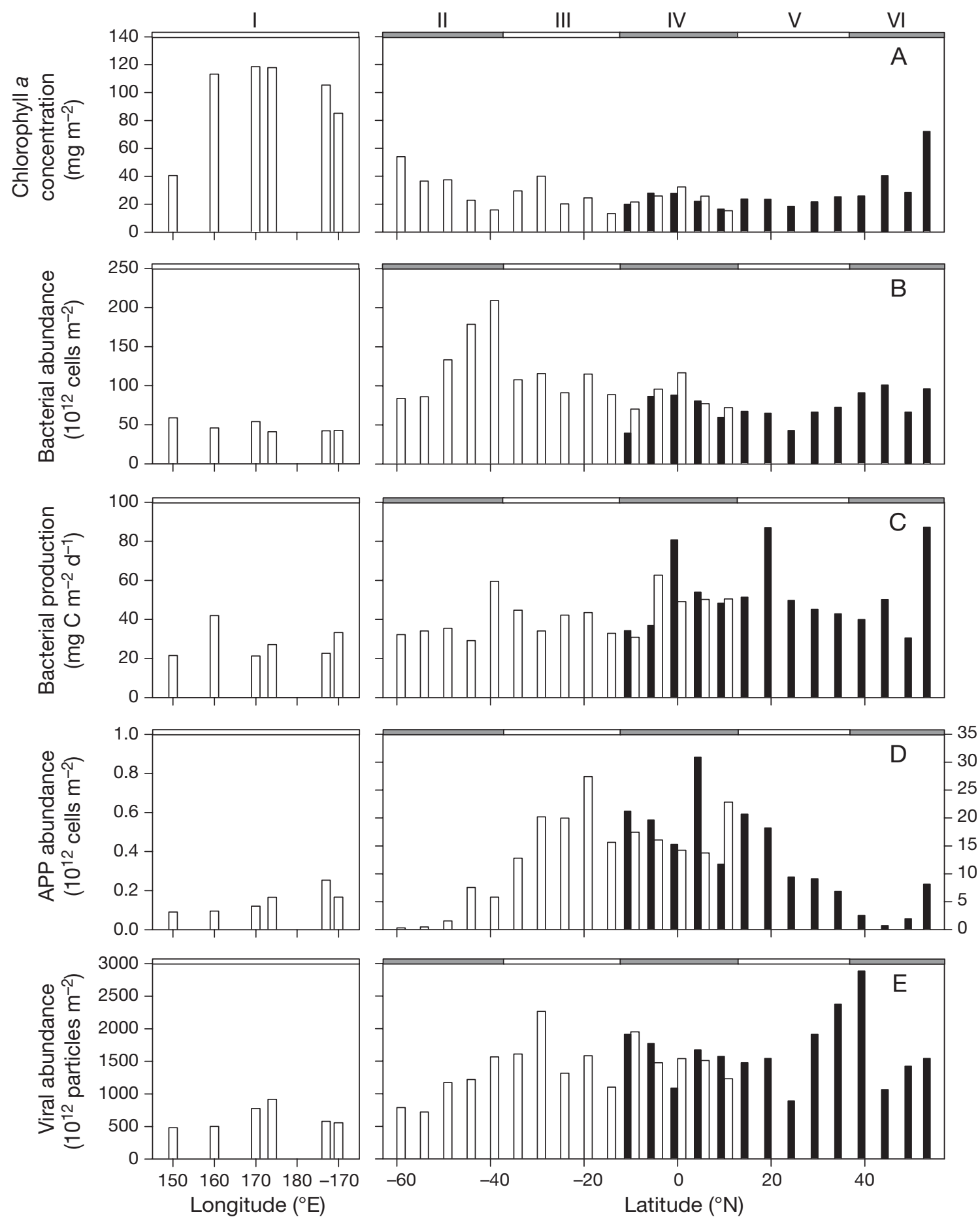

Fig. 3. Depth-integrated (0-200 m) values of (A) chl a concentration, (B) bacterial abundance, (C) bacterial production, (D) photoautotrophic picoplankton (APP) abundance (note the different $y$-axis scales in this panel), and (E) viral abundance across different oceanic regions. The data obtained during cruises KH04-5 and KH05-2 are indicated by open and closed bars, respectively. Regional codes are as follows: I, Antarctic region; II, subantarctic and subtropical convergence zone; III, South Pacific subtropical region; IV, equatorial region; V, North Pacific subtropical region; and VI, subarctic and North Pacific transition zone

tended to be high in subtropical and tropical regions, and low in the Antarctic region. Mean $\pm \mathrm{SD}$ virus to bacteria abundance ratios varied in the range of $8.6 \pm$ $2.4(\mathrm{n}=70$, subantarctic and subtropical convergence zone) and $22.2 \pm 14.4$ ( $\mathrm{n}=104$, equatorial region), with an overall average value of $17.6 \pm 12.5(n=381)$. 

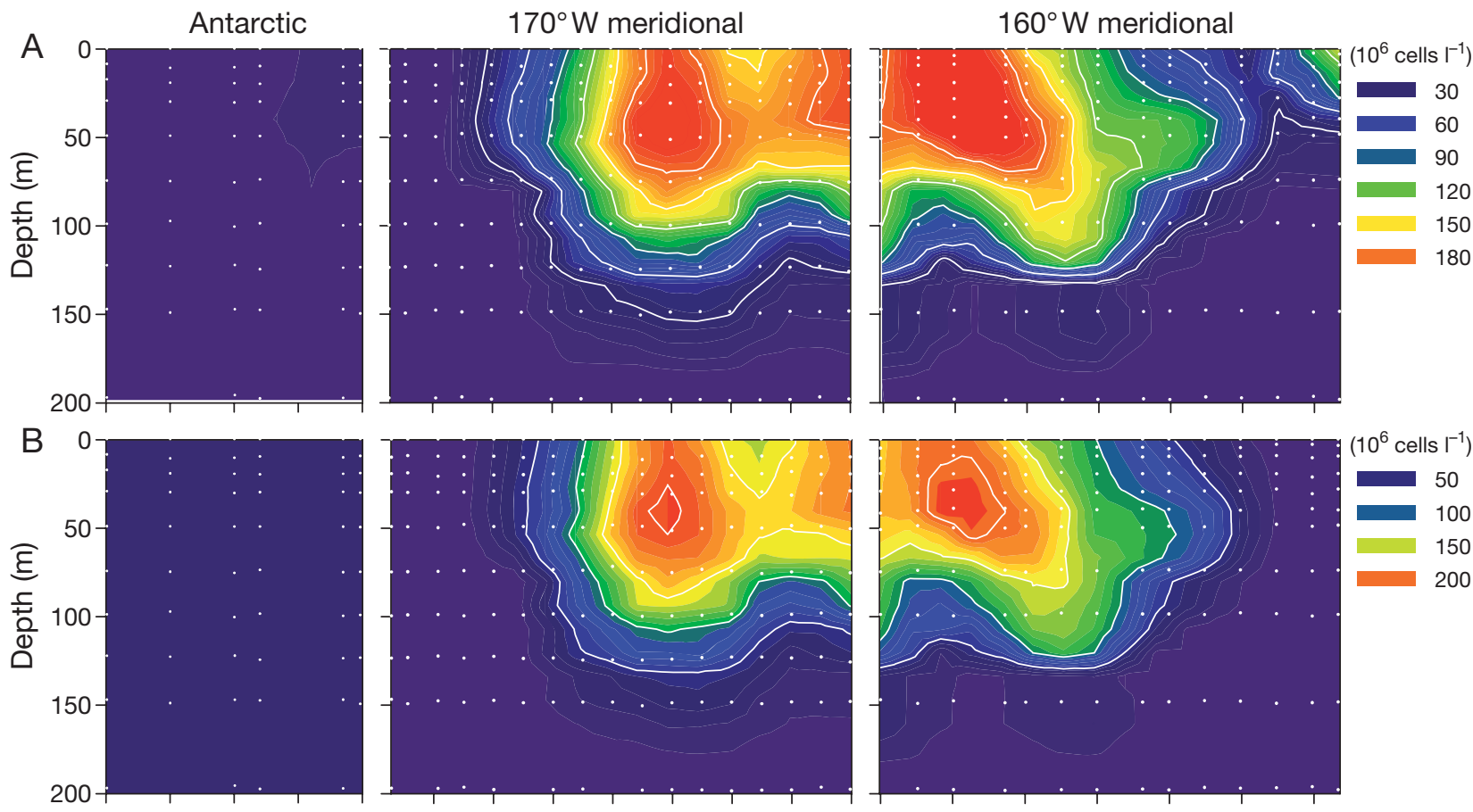

$\left(10^{6}\right.$ cells $\left.~^{-1}\right)$
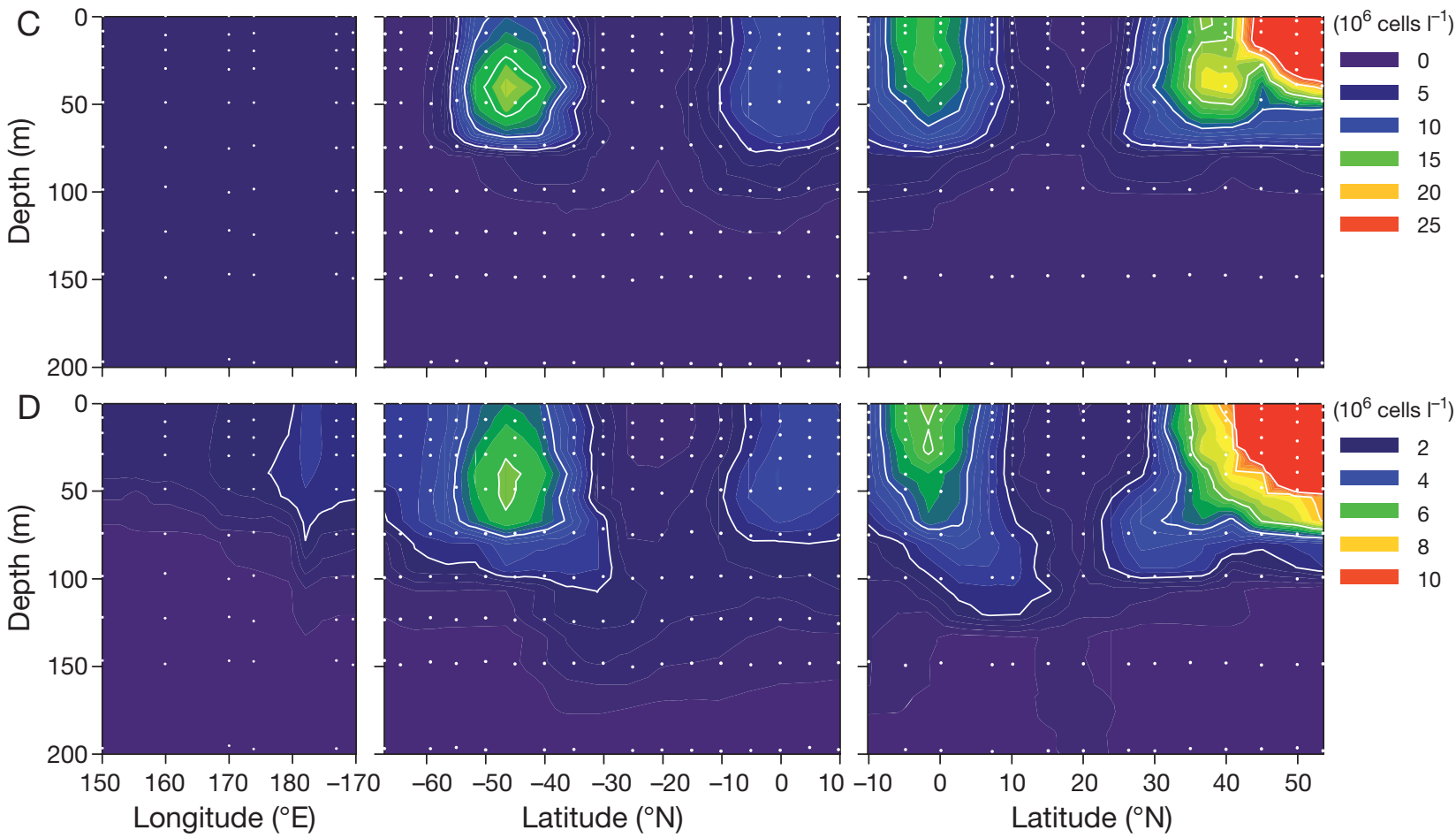

Fig. 4. Distributions of (A) photoautotrophic picoplankton (APP) abundance, (B) Prochlorococcus abundance, (C) Synechococcus abundance, and (D) picoeukaryote abundance along the 3 transects including the Antarctic (Stns SX06 to SX11), 170 ${ }^{\circ} \mathrm{W}$ meridional (Stns SX10 to SX29), and $160^{\circ}$ W meridional (Stns ST01 to ST14). Stns SX10 and SX11 are included in both the Antarctic and $170^{\circ} \mathrm{W}$ meridional transects. See Fig. 1 and Table 1 for the positions and oceanographic parameters of the stations

Three subclusters of viruses were distinguished on the basis of the fluorescence intensity (Fig. 6). These subclusters were denoted as high (HV), medium (MV), and low (LV) fluorescence subclusters. Mean \pm SD ( $\mathrm{n}=$ 386) fluorescence intensities (arbitrary unit, standardized to bead fluorescence) of the HV, MV, and LV sub- 

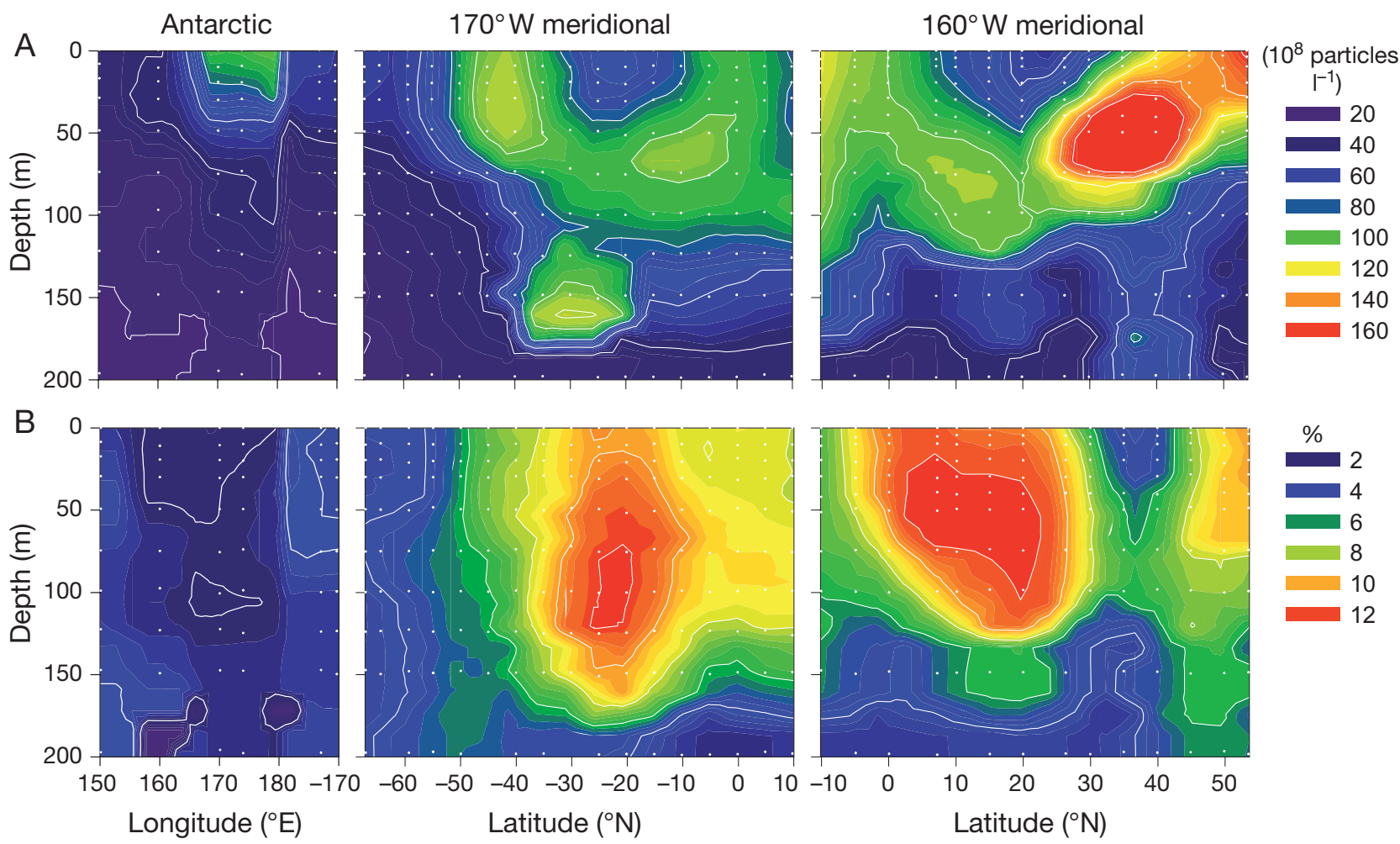

Fig. 5. Distributions of (A) viral abundance and (B) relative percent contributions of the viral subcluster with high fluorescence intensity to total viral abundance (\% HV) along the 3 transects including the Antarctic (Stns SX06 to SX11), 170 ${ }^{\circ} \mathrm{W}$ meridional (Stns SX10 to SX29), and $160^{\circ} \mathrm{W}$ meridional (Stns ST01 to ST14). Stns SX10 and SX11 are included in both the Antarctic and $170^{\circ} \mathrm{W}$ meridional transects. See Fig. 1 and Table 1 for the positions and oceanographic parameters of the stations
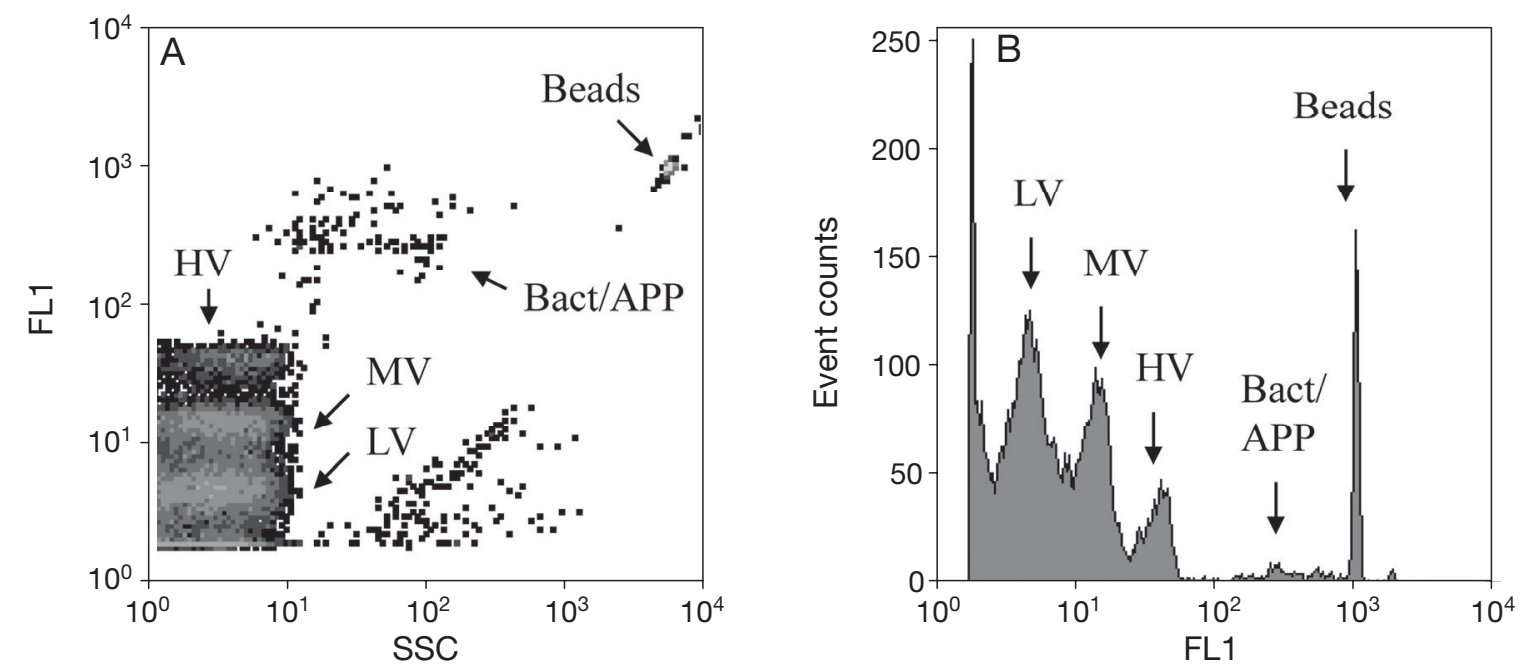

Fig. 6. Example of (A) a density plot (side scatter [SSC] on the $x$-axis and green fluorescence intensity [FL1] on the $y$-axis in log units) and (B) a histogram of viral subclusters discriminated by the difference of the fluorescence intensity (sample collected at a depth of $50 \mathrm{~m}$ at Stn ST13 during cruise KH05-2). HV/MV/LV: viral subcluster with high/medium/low fluorescence intensity; APP: photoautotrophic picoplankton; Bact: bacteria

clusters were $0.0382 \pm 0.0034,0.0134 \pm 0.0010$, and $0.0050 \pm 0.0004$, respectively, which differed significantly from each other (analysis of variance [ANOVA], $\mathrm{p}<0.001)$. Different subclusters displayed distinct patterns in distributions, with regional variability being most pronounced in the HV subcluster. Relative contri- 
butions of the HV subcluster to total viral abundance (\%HV) were high (up to $18.6 \%$ ) in the subtropical and tropical regions, whereas they were low (1.0-6.0\%) in the Antarctic region (Fig. 5B). Relative contributions of the MV and LV subclusters were $28.5 \pm 7.1 \%$ and 64.7 $\pm 9.4 \%$, respectively (mean $\pm \mathrm{SD}, \mathrm{n}=386$ ).

\section{Relationships between viral and environmental variables}

We used a DISTLM approach to determine a set of predictor variables that best explains viral abundance variability for the whole data collected in the present study. Among the environmental variables examined (temperature, depth, chl a concentration, bacterial abundance, bacterial production, Synechococcus abundance, Prochlorococcus abundance, and picoeukaryote abundance; all the variables except for temperature and depth were log-transformed), the best combination of variables was Synechococcus, picoeukrayote, Prochlorococcus abundances, and bacterial production (Table 2). The linear combination of these variables collectively accounted for $58.1 \%$ of variations in viral abundance. Among these variables, Synechococcus abundance accounted for the largest fraction $\left(\mathrm{r}^{2}=0.435\right)$ of viral abundance variability, followed by picoeukaryote abundance $\left(\mathrm{r}^{2}=0.105\right)$, Prochlorococcus abundance $\left(\mathrm{r}^{2}=0.030\right)$, and bacterial production $\left(\mathrm{r}^{2}=0.011\right)$. The 3 APP groups together explained $57.0 \%$ of viral abundance variability. The tolerance value calculated for each predictor variable was high (0.463 to 0.809$)$, indicating that the multi-collinearity problem was minimal. The result of Model II regression analysis is presented in
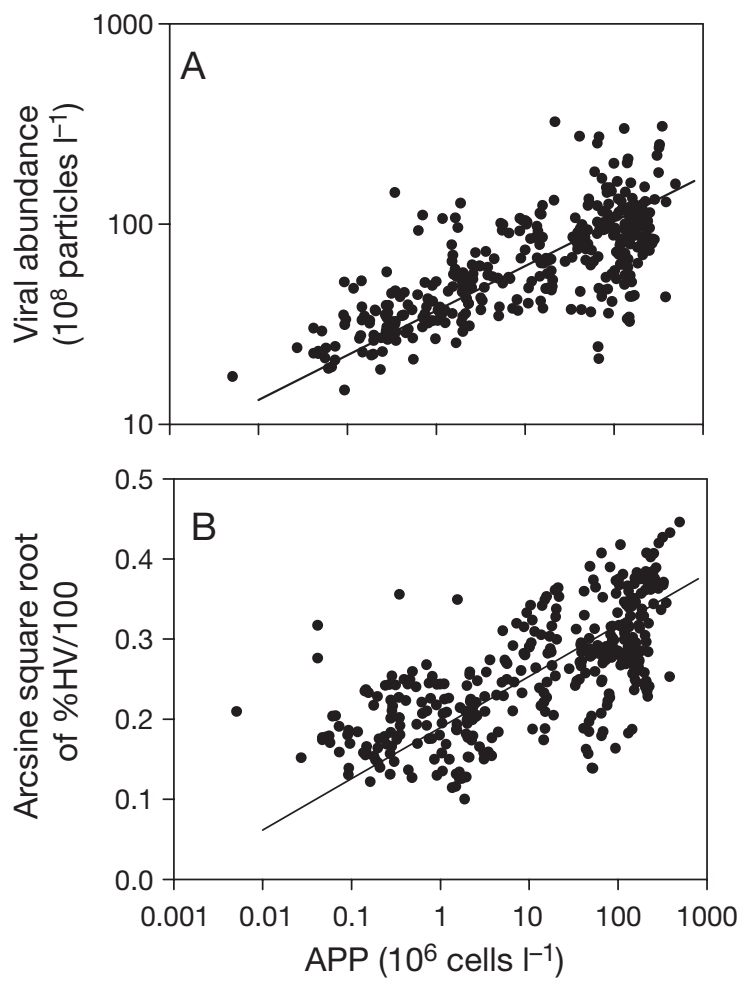

Fig. 7. Relationships between photoautotrophic picoplankton (APP) abundance and (A) viral abundance and (B) relative contributions of the viral subcluster with high fluorescence intensity to total viral abundance (\%HV). Viral abundance and APP abundance were log transformed, whereas \% HV was arcsine square root transformed to reduce skewness (Sokal \& Rohlf 1995). Model II regression equations are as follows $( \pm$ SE): $\log ($ viral abundance $)=1.807( \pm 0.012)+0.223$ $( \pm 0.008) \times \log ($ APP abundance $)$, adjusted $\mathrm{r}^{2}=0.527, \mathrm{p}<0.001$, $\mathrm{n}=381 ;$ Arcsine square root $(\% \mathrm{HV} / 100)=0.189( \pm 0.004)+$ $0.065( \pm 0.002) \times \log ($ APP abundance $)$, adjusted $\mathrm{r}^{2}=0.462$, $\mathrm{p}<0.001, \mathrm{n}=381$

Table 2. Distance-based linear model (DISTLM) results of the best set of environmental variables that account for variations in viral variables for the whole data $(\mathrm{n}=354)$. Viral variables include viral abundance (log transformed) and viral subcluster composition (abundances of individual subclusters). Pseudo- $F$ and $\mathrm{p}$ values were obtained by permutations $(\mathrm{n}=999)$. As the basis of analyses, Euclidean distances and Bray-Curtis similarities were used for viral abundance and viral subcluster composition, respectively. Coefficient is for a linear combination of predictor variables in the formation of the distance-based redundancy analysis (dbRDA) coordinate (Axis 1)

\begin{tabular}{|c|c|c|c|c|c|c|}
\hline Response variable & Selected variables & Pseudo- $F$ & $\mathrm{p}$ & $\mathrm{r}^{2}$ & Coefficient & Tolerance \\
\hline Viral abundance & $\begin{array}{l}\text { Synechococcus abundance } \\
\text { Picoeukaryote abundance } \\
\text { Prochlorococcus abundance } \\
\text { Bacterial production }\end{array}$ & $\begin{array}{r}271.22 \\
79.91 \\
24.41 \\
9.55\end{array}$ & $\begin{array}{l}0.001 \\
0.001 \\
0.001 \\
0.004\end{array}$ & $\begin{array}{c}0.435 \\
0.105 \\
0.030 \\
0.011 \\
(0.581)^{\mathrm{a}}\end{array}$ & $\begin{array}{l}0.062 \\
0.088 \\
0.019 \\
0.057\end{array}$ & $\begin{array}{l}0.596 \\
0.539 \\
0.809 \\
0.463\end{array}$ \\
\hline $\begin{array}{l}\text { Viral subcluster } \\
\text { composition }\end{array}$ & $\begin{array}{l}\text { Synechococcus abundance } \\
\text { Picoeukaryote abundance } \\
\text { Prochlorococcus abundance } \\
\text { Bacterial production }\end{array}$ & $\begin{array}{r}186.71 \\
47.68 \\
21.30 \\
11.47\end{array}$ & $\begin{array}{l}0.001 \\
0.001 \\
0.001 \\
0.001\end{array}$ & $\begin{array}{c}0.347 \\
0.078 \\
0.033 \\
0.017 \\
(0.475)^{\mathrm{a}}\end{array}$ & $\begin{array}{l}2.500 \\
2.905 \\
0.838 \\
2.723\end{array}$ & $\begin{array}{l}0.596 \\
0.539 \\
0.809 \\
0.463\end{array}$ \\
\hline
\end{tabular}


Fig. 7A, indicating a strong positive relationship between viral abundance and total APP abundance.

The relationship between viral abundance and environmental variables differed among different oceanic regions (Table 3). For the subset of data obtained in the Antarctic region, chl a concentrations accounted for a substantial fraction of variations in viral abundance $\left(\mathrm{r}^{2}\right.$ $=0.659, \mathrm{n}=55, \mathrm{p}<0.001$ ), whereas the contribution of bacterial abundance was moderate $\left(\mathrm{r}^{2}=0.071\right)$. In contrast, bacterial abundance was the best predictor of viral abundance in the subantarctic/convergence zone $\left(\mathrm{r}^{2}=0.853, \mathrm{n}=69, \mathrm{p}<0.001\right)$. Chl a concentration explained only $1 \%$ of variation in viral abundance in this region. For other regions, the strongest predictor variables included bacterial abundance in the South Pacific subtropical gyre $\left(\mathrm{r}^{2}=0.401, \mathrm{n}=46, \mathrm{p}<0.001\right)$, temperature in the equatorial zone $\left(\mathrm{r}^{2}=0.505, \mathrm{n}=97, \mathrm{p}\right.$ $<0.001$ ), and the abundance of picoeukaryotes in the subtropical gyre of the North Pacific $\left(\mathrm{r}^{2}=0.399, \mathrm{n}=45\right.$, $\mathrm{p}<0.001)$ and the subarctic gyre $\left(\mathrm{r}^{2}=0.656, \mathrm{n}=42, \mathrm{p}<\right.$ $0.001)$.
The DISTLM routines were also used to examine the relationship between viral subcluster composition and environmental variables using the Bray-Curtis similarity as a basis of the analysis. Four variables (Synechococcus abundance, picoeukaryote abundance, Prochlorococcus abundance, and bacterial production) were selected as the best set of predictor variables (overall $\mathrm{r}^{2}=0.475$; tolerance values, 0.463 to $0.809 ;$ Table 2). The sum of the $r^{2}$ s for the 3 groups of APP was 0.458, suggesting that APP abundance accounted for a large fraction of the variability in viral subcluster compositions. In order to examine the mode of the change in the viral subcluster composition along the gradient of APP abundance, relationships between the relative abundances of individual subclusters of viruses ( $\% \mathrm{HV}, \% \mathrm{MV}$, and \%LV) and total APP abundance were examined on the basis of the Model II regression. The results indicated that $\% \mathrm{HV}$ was significantly positively related to APP abundance $\left(\mathrm{r}^{2}=0.462 ; \mathrm{p}<0.001, \mathrm{n}=381\right.$; Fig. 7B). The relationships between the relative

Table 3. Distance Based Linear Model (DISTLM) results of the best set of environmental variables that account for variations in viral abundance for individual oceanic regions ( $\mathrm{n}$ = number of samples). Prochlorococcus and Synechococcus were not used as environmental variables for the Antarctic region because these microbes were not detected. Pseudo- $F$ and $p$ values were obtained by permutations $(\mathrm{n}=999)$. Euclidean distances were used as the basis of the analyses. Coefficient is for a linear combination of predictor variables in the formation of the distance based redundancy analysis (dbRDA) coordinate (Axis 1)

\begin{tabular}{|c|c|c|c|c|c|c|}
\hline Region & Selected variables & Pseudo-F & $\mathrm{p}$ & $\mathrm{r}^{2}$ & Coefficient & Tolerance \\
\hline $\begin{array}{l}\text { Antarctic region } \\
(\mathrm{n}=55)\end{array}$ & $\begin{array}{l}\text { Chl a concentration } \\
\text { Bacterial abundance } \\
\text { Depth }\end{array}$ & $\begin{array}{r}102.64 \\
13.81 \\
12.69\end{array}$ & $\begin{array}{l}0.001 \\
0.002 \\
0.003\end{array}$ & $\begin{array}{c}0.659 \\
0.071 \\
0.054 \\
(0.785)^{\mathrm{a}}\end{array}$ & $\begin{array}{r}0.174 \\
-0.438 \\
-0.004\end{array}$ & $\begin{array}{l}0.258 \\
0.816 \\
0.258\end{array}$ \\
\hline $\begin{array}{l}\text { Subantarctic \& } \\
\text { subtropical } \\
\text { convergence } \\
\text { zone }(\mathrm{n}=69)\end{array}$ & $\begin{array}{l}\text { Bacterial abundance } \\
\text { Temperature } \\
\text { Bacterial production } \\
\text { Chl a concentration } \\
\text { Depth }\end{array}$ & $\begin{array}{r}388.31 \\
12.64 \\
13.80 \\
9.20 \\
4.22\end{array}$ & $\begin{array}{l}0.001 \\
0.001 \\
0.001 \\
0.004 \\
0.048\end{array}$ & $\begin{array}{c}0.853 \\
0.024 \\
0.022 \\
0.013 \\
0.006 \\
(0.917)^{\mathrm{a}}\end{array}$ & $\begin{array}{r}0.489 \\
0.019 \\
0.076 \\
-0.064 \\
-0.001\end{array}$ & $\begin{array}{l}0.493 \\
0.750 \\
0.157 \\
0.556 \\
0.230\end{array}$ \\
\hline $\begin{array}{l}\text { South Pacific } \\
\text { subtropical } \\
\text { region }(n=46)\end{array}$ & $\begin{array}{l}\text { Bacterial abundance } \\
\text { Synechococcus abundance } \\
\text { Picoeukaryote abundance }\end{array}$ & $\begin{array}{r}29.43 \\
4.99 \\
4.20\end{array}$ & $\begin{array}{l}0.001 \\
0.039 \\
0.054\end{array}$ & $\begin{array}{c}0.401 \\
0.062 \\
0.049 \\
(0.512)^{\mathrm{a}}\end{array}$ & $\begin{array}{r}0.909 \\
-0.116 \\
0.136\end{array}$ & $\begin{array}{l}0.180 \\
0.214 \\
0.549\end{array}$ \\
\hline $\begin{array}{l}\text { Equatorial } \\
\text { region }(\mathrm{n}=97)\end{array}$ & $\begin{array}{l}\text { Temperature } \\
\text { Picoeukaryote abundance }\end{array}$ & $\begin{array}{l}96.89 \\
20.64\end{array}$ & $\begin{array}{l}0.001 \\
0.001\end{array}$ & $\begin{array}{c}0.505 \\
0.089 \\
(0.594)^{\mathrm{a}}\end{array}$ & $\begin{array}{l}0.038 \\
0.113\end{array}$ & $\begin{array}{l}0.420 \\
0.307\end{array}$ \\
\hline $\begin{array}{l}\text { North Pacific } \\
\text { subtropical } \\
\text { region }(\mathrm{n}=45)\end{array}$ & $\begin{array}{l}\text { Picoeukaryote abundance } \\
\text { Temperature } \\
\text { Bacterial abundance } \\
\text { Depth } \\
\text { Bacterial production } \\
\text { Synechococcus abundance }\end{array}$ & $\begin{array}{r}28.58 \\
12.65 \\
16.27 \\
19.07 \\
12.75 \\
5.45\end{array}$ & $\begin{array}{l}0.001 \\
0.003 \\
0.001 \\
0.001 \\
0.004 \\
0.025\end{array}$ & $\begin{array}{c}0.399 \\
0.139 \\
0.131 \\
0.107 \\
0.055 \\
0.021 \\
(0.853)^{\mathrm{a}}\end{array}$ & $\begin{array}{r}0.152 \\
-0.026 \\
1.087 \\
0.013 \\
0.240 \\
0.098\end{array}$ & $\begin{array}{l}0.490 \\
0.592 \\
0.283 \\
0.218 \\
0.169 \\
0.289\end{array}$ \\
\hline $\begin{array}{l}\text { Subarctic \& } \\
\text { North Pacific } \\
\text { transition zone } \\
(\mathrm{n}=42)\end{array}$ & $\begin{array}{l}\text { Picoeukaryote abundance } \\
\text { Bacterial abundance }\end{array}$ & $\begin{array}{l}76.12 \\
12.10\end{array}$ & $\begin{array}{l}0.001 \\
0.005\end{array}$ & $\begin{array}{c}0.656 \\
0.082 \\
(0.737)^{\mathrm{a}}\end{array}$ & $\begin{array}{l}0.108 \\
0.349\end{array}$ & $\begin{array}{l}0.637 \\
0.637\end{array}$ \\
\hline
\end{tabular}


abundances of other subclusters and APP abundance were weak $\left(\mathrm{r}^{2}=0.039\right.$ and 0.173 for $\% \mathrm{MV}$ and \%LV, respectively).

\section{Subsurface viral peak in the mid-latitude regions of the North Pacific}

The subsurface viral peak found in the mid-latitude regions of the North Pacific did not coincide with the maxima of biotic variables studied (Figs. 2 \& 4). However, this viral peak coincided with the dissolved oxygen anomaly (the excess above saturation) indicated

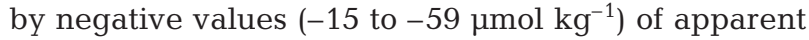
oxygen utilization (AOU; Fig. 8A). Both peaks have a center near the $\sigma_{\theta}=24.5$ to 25.5 isopycnal $\left(\sigma_{\theta}\right.$ is the potential density in $\mathrm{kg} \mathrm{m}^{-3}$ - 1000) with a maximum thickness of about $50 \mathrm{~m}$, shoaling north along isopycnal surfaces below the pycnocline (Fig. 8B). For the data collected in the upper layer $(\leq 100 \mathrm{~m})$ between $25^{\circ}$ and $45^{\circ} \mathrm{N}$, viral abundance was negatively correlated with AOU (Pearson's $\mathrm{r}=0.69, \mathrm{p}<0.0001, \mathrm{n}=$ $40)$. Among the 3 viral subclusters, the correlation with AOU was strongest for the abundance of the MV subcluster $(r=0.73, p<0.0001)$ followed by the LV subcluster $(\mathrm{r}=0.64, \mathrm{p}<0.0001)$, whereas it was relatively weak $(\mathrm{r}=0.52, \mathrm{p}<0.0005)$ for the HV subcluster.

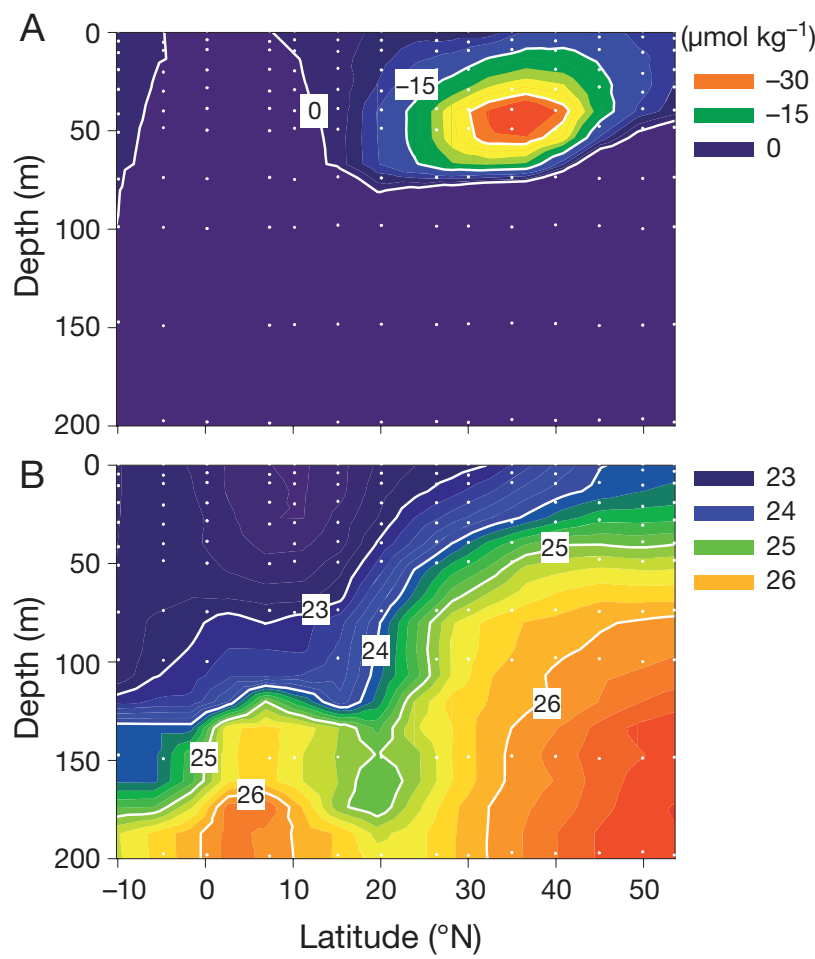

Fig. 8. Spatial variations of (A) apparent oxygen utilization (AOU) and (B) $\sigma_{\theta}$ along the $160^{\circ} \mathrm{W}$ meridional transect. $\left(\sigma_{\theta}\right.$ is the potential density in $\mathrm{kg} \mathrm{m}^{-3}-1000$ )

\section{DISCUSSION}

Despite the increasing recognition that viruses are important components in marine ecosystems, the data on viral distributions and production in open oceans are still limited (Weinbauer 2004, Motegi \& Nagata 2007). In addition, cross-system comparisons of viral distributions using data reported in the literature are compromised because of the large variations in viral counts among studies using different methods (Brussaard 2004, Wen et al. 2004). In fact, the compilation of the available data on viral abundance in open oceans hardly reveals patterns in distributions across different oceanographic regions. Our results collected across various oceanic regions (including polar, subpolar, subtropical, and tropical oceans) revealed novel features regarding large-scale viral distributions in the upper oceans.

\section{Viral distributions and their relationships with environmental variables}

Over the broad scale, the abundances of the 3 groups of APP were the best predictor of viral abundance, accounting for $57 \%$ of the variability. The positive relationship between viral abundance and the APP abundances may partly reflect vertical distribution patterns of these variables. However, our results obtained using DISTLM indicated that depth does not add significantly to the ability of the model to explain viral abundance variability. Thus, the positive relationship between viral and APP abundances should reflect regional variations. Indeed, viruses tended to be more abundant in lower latitude regions where total APP abundances were high, while viruses tended to be less abundant in the Antarctic region where total APP abundances were low. High abundances of viruses in subtropical and tropical regions might be partly accounted for by high abundances of cyanophages infecting APP (Mann 2003). Recent studies have revealed that these viruses carry many functional genes of the host, which allow them to effectively proliferate in oligotrophic oceanic environments (Mann et al. 2003, 2005, Sullivan et al. 2006, Williamson et al. 2008). Metagenomic analysis on phage sequences in fosmid clone libraries also indicated that cyanophages may be numerically dominant in the euphotic zone of the subtropical North Pacific with 60 to $80 \%$ of total intracellular $(0.22$ to $1.6 \mu \mathrm{m})$ virus sequences (which appeared to originate from replicating viruses within infected hosts) described as cyanophage-like (DeLong et al. 2006). The above information suggests that cyanophages might be an important component of viral communities especially in subtropical and tropi- 
cal oceans where cyanobacteria can account for a significant fraction (10 to $30 \%$ ) of total prokaryote abundance (Campbell et al. 1994). However, it should be stressed that the data on turnover of host and viral communities in open oceans are scarce (Baudoux et al. 2007), suggesting a need for future studies that examine the magnitude of viral lytic pressures on APP communities in diverse oceanic systems.

We found that relationships between viral abundance and biotic variables differed among regions, which indicates that controls of virus-host systems are largely distinct among different oceanic habitats. The strong positive relationship between bacterial and viral abundance that we found in the subantarctic/subtropical convergence zone is consistent with the results of previous studies conducted in subarctic regions (Steward et al. 1996). A close coupling between lytic viruses and bacteria in the subantarctic region $\left(48^{\circ} \mathrm{S}\right.$; the Atlantic sector of the Southern Ocean) was suggested by Weinbauer et al. (2009), who found that percentages of bacteria infected by viruses were high (21 to $40 \%$ ) especially in the Fe-fertilized patch. The above data corroborate the proposition that bacteria are the major host of viral communities in subpolar regions. In contrast, chl a concentration was a strong predictor of viral abundance in the Antarctic region where APP abundances were low. This result might indicate that viruses infecting larger phytoplankton were prominent in this oceanic region at the time of our sampling. Consistent with our results, Brussaard et al. (2008) noted that viral abundance in natural Fe-fertilized waters southeast of the Kerguelen Islands (south of the Polar Front) was more variable than bacterial abundance and displayed a higher positive correlation with chl a $(\mathrm{r}=0.587)$ than bacterial abundance $(\mathrm{r}=$ 0.240 ). It is likely that interactions between viruses and hosts dynamically change in response to changes in environmental conditions in subpolar and polar oceans where variations over seasons and across the regions in host community structures, primary productivity, and light and nutrient regimes are large.

\section{Viral subclusters}

Viral subclusters with different fluorescence intensities reflect differences in the viral genome size (Baudoux \& Brussaard 2005), although other factors (e.g. accessibility of dyes to nucleic acids) may also affect fluorescence intensities (Brussaard 2004). Each viral subcluster may consist of multiple taxonomic groups of viruses with different hosts, i.e. viruses with different genome size can infect the same species of host, while viruses with the same genome size can infect a diverse range of hosts (e.g. Mann 2003, Baudoux \& Brussaard
2005). Nonetheless, field studies have found that distinct viral subclusters tend to display different dynamics (Larsen et al. 2008) and distributions (Brussaard et al. 2008), suggesting that they broadly represent viral subpopulations with different hosts (Marie et al. 1999, Suttle 2007, Brussaard et al. 2008, Larsen et al. 2008). Based on the observations that HV subclusters covary with algal abundance (Marie et al. 1999, Larsen et al. 2008), these viruses have been generally suggested to contain cyanophages and algal viruses (Brussaard et al. 2008). Few data are available about viral subclusters distinguished by flow cytometry in open ocean environments, and our data are among the first to document a large-scale pattern in distributions of $\mathrm{HV}$ viruses across different oceanic regions.

We found that the distribution of \%HV was consistent with that of APP, as indicated by a significant positive relationship between \%HV and total APP abundance. Our results showing low \%HV values in the Antarctic region are consistent with the data of Brussaard et al. (2008), who reported that \%HV was low (generally $<6 \%$ ) at stations south of the Polar Front, although the authors did not compare these values with those in lower latitude regions. Obviously, statistical relationships alone cannot prove the existence of the link between specific hosts and viral subclusters. Nonetheless, our results are consistent with the hypothesis that HV viruses include many viruses infecting APP especially in tropical and subtropical waters (Brussaard et al. 2008). Further studies are required to examine taxonomic compositions of viruses belonging to different subclusters with the use of molecular analyses of viral genes (Breitbart et al. 2002, Breitbart \& Rohwer 2005, Williamson et al. 2008).

\section{Viral 'hot spot' in mid-latitudes of the North Pacific}

A striking feature that we found in the North Pacific is a pronounced peak of viruses associated with a dissolved oxygen anomaly. The development of a subsurface oxygen anomaly between spring and late summer is a prominent feature in mid-latitude regions of the North Pacific (Shulenberger \& Reid 1981, Jenkins \& Goldman 1985, Najjar \& Keeling 1997). The oxygen anomaly reflects the accumulation of net photosynthetic production (new production) of oxygen between spring and late summer within a zone below the mixed layer and above the compensation depth, where ventilation of oxygen into the air is impeded due to stratification. The subsurface anomaly is a seasonal phenomenon that disappears with the deepening of the mixed layer in the fall season. The level of the anomaly (AOU $=-15$ to $-59 \mu \mathrm{mol} \mathrm{kg}{ }^{-1}$ ) at the time of our investigation (September) is near the seasonal maximum typically 
observed in this region (Shulenberger \& Reid 1981). Note that the oxygen anomaly in a subsurface layer does not necessarily imply high primary production in that layer (Shulenberger \& Reid 1981). In fact, our data showed that the layer of oxygen anomaly did not coincide with peaks of phototrophs (i.e. chl a concentration, APP abundance) and heterotrophs (i.e. bacterial abundance and production). Therefore, high viral abundance associated with the oxygen anomaly cannot be simply explained by the spatial distributions of potential hosts.

We hypothesize that combined effects of physical processes and host distributions account for the coincidence of high viral abundance and the oxygen anomaly. As mentioned above, oxygen gas in the layer of the anomaly does not ventilate because it is isolated from the mixed layer. This suggests that viruses in the oxygen anomaly layer are also isolated from the mixed layer where UV radiation destroys viruses. High impacts of UV radiation on viral survival and distribution in the mixed layer of the oceanic water column have been documented by several studies (e.g. Weinbauer 2004). Murray \& Jackson (1993) developed a model to examine the interaction of UV radiation and mixing processes on virus survival in upper waters. They concluded that viruses not subject to mixing (as would be the case for viruses in the oxygen anomaly layer) have much lower mortality rates than those in the mixed layer. Thus, the zone of oxygen anomaly could be a 'refuge' for viruses where they escape from UV-induced destruction and encounter more abundant hosts compared to those available for viruses in the layer below the compensation depth. It is intriguing to speculate that viral communities differ in compositions between the surface mixed layer and the subsurface zone of oxygen anomaly. Our data on viral subcluster compositions partly support this notion, since AOU was more strongly correlated with the abundance of the MV subcluster than with the abundances of other subclusters. Clarifying how different communities of viruses regulate bacterial and algal communities in distinct zones of the euphotic layer is crucial for a better understanding of oceanic ecosystem functioning, given the huge physical dimension and large contributions to global biogeochemical cycles of the transitional and subtropical regions of the North Pacific.

\section{CONCLUSIONS}

Our results revealed that the abundances of APP, including Prochlorococcus, Synechococcus, and picoeukaryotes, are major factors explaining variations in viral abundance and subcluster composition over a large scale. The data also provided evidence in sup- port of the notion that the HV subcluster might contain large amounts of viruses infecting APP, a possibility that should be investigated using molecular analyses of viral genes affiliated with different viral subclusters. We also found that the relationships between viral abundance and biotic variables are distinct among different oceanographic regions, especially in polar and subpolar regions, noting that viruses respond dynamically to changes in host community structures and environmental conditions in these regions. The occurrence of a 'viral hot spot' in the zone of a subsurface oxygen anomaly in the North Pacific has led us to hypothesize that there are 2 distinctive habitats (i.e. mixed layer and 'viral refuge') for viruses to proliferate in the euphotic layer with a seasonal pycnocline. In short, our data demonstrate that combined effects of host distributions, mixing, and UV radiation generate outstanding geographic patterns in viral distributions in the upper oceans, suggesting a need for future studies on geographic variability in viral taxonomic compositions, their functional attributes, and viral-mediated biogeochemical cycles in oceanic ecosystems.

Acknowledgements. This study was supported by the Dynamics of the Ocean Biosystems project (Grant-in-Aid for Creative Basic Research 12NP0201 from the Ministry of Education, Culture, Sports, Science, and Technology-Japan). Financial support was also provided by Japan Society for the Promotion of Science (JSPS) grants (17201004, 20310010, 22651004) and the $21^{\text {st }}$ Century Centers of Excellence Program of Kyoto University. Y.Y. was supported by the JSPS Postdoctoral Fellowship for Foreign Researchers. We thank captains, officers, and crews of RV 'Hakuho-maru' for logistic support during the cruises. C. Brussaard provided helpful information regarding flow cytometric counting of viruses.

\section{LITERATURE CITED}

Anderson MJ, Gorley RN, Clarke KR (2008) PERMANOVA+ for PRIMER: guide to software and statistical methods. PRIMER-E, Plymouth

Baudoux AC, Brussaard CPD (2005) Characterization of different viruses infecting the marine harmful algal bloom species Phaeocystis globosa. Virology 341:80-90

Baudoux AC, Veldhuis MJW, Witte HJ, Brussaard CPD (2007) Viruses as mortality agents of picophytoplankton in the deep chlorophyll maximum layer during IRONAGES III. Limnol Oceanogr 52:2519-2529

Breitbart M, Rohwer F (2005) Here a virus, there a virus, everywhere the same virus? Trends Microbiol 13:278-284

Breitbart M, Salamon P, Andresen B, Mahaffy JM, Segall AM, Mead D, Azam F, Rohwer F (2002) Genomic analysis of uncultured marine viral communities. Proc Natl Acad Sci USA 99:14250-14255

Breitbart M, Middelboe M, Rohwer F (2008) Marine viruses: community dynamics, diversity and impact on microbial processes. In: Kirchman DL (ed) Microbial ecology of the oceans, 2nd edn. Wiley-Blackwell, Hoboken, NJ, p 443-479

Brussaard CPD (2004) Optimization of procedures for counting viruses by flow cytometry. Appl Environ Microbiol 70: 1506-1513 
Brussaard CPD, Timmermans KR, Uitz J, Veldhuis MJW (2008) Virioplankton dynamics and virally induced phytoplankton lysis versus microzooplankton grazing southeast of the Kerguelen (Southern Ocean). Deep-Sea Res II 55: $752-765$

Campbell L (2001) Flow cytometric analysis of autotrophic picoplankton. In: Paul JH (ed) Methods in microbiology, Vol 30. Academic Press, San Diego, CA, p 317-343

Campbell L, Nolla HA, Vaulot D (1994) The importance of Prochlorococcus to community structure in the central North Pacific Ocean. Limnol Oceanogr 39:954-961

Culley AI, Welschmeyer NA (2002) The abundance, distribution, and correlation of viruses, phytoplankton, and prokaryotes along a Pacific Ocean transect. Limnol Oceanogr 47:1508-1513

De Paepe M, Taddei F (2006) Viruses' life history: towards a mechanistic basis of a trade-off between survival and reproduction among phages. PLoS Biol 4:e193 doi:10. 1371/journal.pbio.0040193

DeLong EF, Preston CM, Mincer T, Rich V and others (2006) Community genomics among stratified microbial assemblages in the ocean's interior. Science 311:496-503

Fuhrman JA (1999) Marine viruses and their biogeochemical and ecological effects. Nature 399:541-548

Gonzalez JM, Suttle CA (1993) Grazing by marine nanoflagellates on viruses and virus-sized particles: ingestion and digestion. Mar Ecol Prog Ser 94:1-10

Heldal M, Bratbak G (1991) Production and decay of viruses in aquatic environments. Mar Ecol Prog Ser 72:205-212

Jenkins WJ, Goldman JC (1985) Seasonal oxygen cycling and primary production in the Sargasso Sea. J Mar Res 43: 465-491

Kirchman D (2001) Measuring bacterial biomass production and growth rates from leucine incorporation in natural aquatic environments. In: Paul JH (ed) Methods in microbiology, Vol 30. Academic Press, San Diego, CA, p 227-237

- Larsen JB, Larsen A, Thyrhaug R, Bratbak G, Sandaa RA (2008) Response of marine viral populations to a nutrient induced phytoplankton bloom at different $\mathrm{pCO}_{2}$ levels. Biogeosciences 5:523-533

Li WKW, Dickie PM (2001) Monitoring phytoplankton, bacterioplankton, and virioplankton in a coastal inlet (Bedford Basin) by flow cytometry. Cytometry 44:236-246

Longhurst A (2006) Ecological geography of the sea, 2nd edn. Academic Press, San Diego, CA

Mann NH (2003) Phages of the marine cyanobacterial picophytoplankton. FEMS Microbiol Rev 27:17-34

Mann NH, Cook A, Millard A, Bailey S, Clokie M (2003) Bacterial photosynthesis genes in a virus. Nature 424:741

- Mann NH, Clokie MRJ, Millard A, Cook A, Wilson WH, Wheatley PJ, Letarov A, Krisch HM (2005) The genome of S-PM2, a "photosynthetic" T4-type bacteriophage that infects marine Synechococcus strains. J Bacteriol 187:3188-3200

Marie D, Brussaard CPD, Thyrhaug R, Bratbak G, Vaulot D (1999) Enumeration of marine viruses in culture and natural samples by flow cytometry. Appl Environ Microbiol 65:45-52

Motegi C, Nagata T (2007) Enhancement of viral production

Editorial responsibility: Curtis Suttle,

Vancouver, Canada by addition of nitrogen or nitrogen plus carbon in subtropical surface waters of the South Pacific. Aquat Microb Ecol 48:27-34

> Motegi C, Nagata T (2009) Addition of monomeric and polymeric organic substrates alleviates viral lytic pressure on bacterial communities in coastal seawaters. Aquat Microb Ecol 57:343-350

Motegi C, Nagata T, Miki T, Weinbauer MG, Legendre L, Rassoulzadegan F (2009) Viral control of bacterial growth efficiency in marine pelagic environments. Limnol Oceanogr 54:1901-1910

- Murray AG, Jackson GA (1993) Viral dynamics II: a model of the interaction of ultraviolet light and mixing processes on virus survival in seawater. Mar Ecol Prog Ser 102:105-114

> Najjar RG, Keeling RF (1997) Analysis of the mean annual cycle of the dissolved oxygen anomaly in the World Ocean. J Mar Res 55:117-151

> Noble RT, Fuhrman JA (1997) Virus decay and its causes in coastal waters. Appl Environ Microbiol 63:77-83

Proctor LM, Fuhrman JA (1991) Roles of viral infection in organic particulate flux. Mar Ecol Prog Ser 69:133-142

Quinn GP, Keough MJ (2002) Experimental design and data analysis for biologists. Cambridge University Press, Cambridge

Shulenberger E, Reid JL (1981) The Pacific shallow oxygen maximum, deep chlorophyll maximum, and primary productivity, reconsidered. Deep-Sea Res A Oceanogr Res Pap 28:901-919

Sokal RR, Rohlf FJ (1995) Biometry: the principles and practices of statistics in biological research, 3rd edn. Freeman, New York, NY

> Steward GF, Smith DC, Azam F (1996) Abundance and production of bacteria and viruses in the Bering and Chukchi Seas. Mar Ecol Prog Ser 131:287-300

Sullivan MB, Lindell D, Lee JA, Thompson LR, Bielawski JP, Chisholm SW (2006) Prevalence and evolution of core photosystem II genes in marine cyanobacterial viruses and their hosts. PLoS Biol 4:e234 doi:10.1371/journal.pbio. 0040234

Suttle CA (2007) Marine viruses-major players in the global ecosystem. Nat Rev Microbiol 5:801-812

Suttle CA, Chen F (1992) Mechanisms and rates of decay of marine viruses in seawater. Appl Environ Microbiol 58: 3721-3729

> Weinbauer MG (2004) Ecology of prokaryotic viruses. FEMS Microbiol Rev 28:127-181

Weinbauer MG, Arrieta JM, Griebler C, Herndl GJ (2009) Enhanced viral production and infection of bacterioplankton during an iron-induced phytoplankton bloom in the Southern Ocean. Limnol Oceanogr 54:774-784

Wen K, Ortmann AC, Suttle CA (2004) Accurate estimation of viral abundance by epifluorescence microscopy. Appl Environ Microbiol 70:3862-3867

Williamson SJ, Rusch DB, Yooseph S, Halpern AL and others (2008) The Sorcerer II global ocean sampling expedition: metagenomic characterization of viruses within aquatic microbial samples. PLoS ONE 3:e1456 doi:10.1371/journal.pone.0001456

Submitted: September 14, 2009; Accepted: May 18, 2010 Proofs received from author(s): June 28, 2010 